\title{
Major B. F. S. BADEN-POWELL, Honorary Fellow
}

\author{
(1860-1937)
}

\author{
Founder of the "Aeronautical Journal", which celebrates its \\ Sixtieth Birthday with this issue
}

\section{AN APPRECIATION}

by

J. LAURENCE PRITCHARD, Honorary Fellow

"A man of hope and forward looking mind"

Wordsworth.

\begin{abstract}
$F^{\circ}$
OR FIFTY SEVEN YEARS Baden F. S. BadenPowell was part of the history of the Aeronautical Society. He was elected a member of it on 21st April, 1880, when he was just twenty years old. In 1886 he became a member of Council and served on it without a break for a quarter of a century. In 1896 he became Honorary Secretary, and in 1900 was elected President, a position he held for eight years, when the usual order of things was reversed and he was elected VicePresident. In 1919, just on forty years after he had joined the Society, Major Baden-Powell was elected an Honorary Fellow. He died on 3rd October, 1937.

That is a record without parallel in the Society's long history, and one little known in any detail. It is not possible to give more than a passing reference to much that he did and was interested in during his long and very active life, for he was a man of exceptional energy, a characteristic of his family. His brother, Lord Baden-Powell, became founder of that astonishing world movement, the Boy Scouts.

In 1880, the year he joined the Society, "I witnessed my first ascent," Baden-Powell wrote some years later in his book Ballooning as a Sport, " and got to know some of the aeronauts of the day. In that year I joined the Aeronautical Society - which, by the way, was then rather laughed at, because the members would talk in a dreamy way about flying machines instead of devoting themselves to the practical and existing appliance, the balloon!"

From that year the young Baden-Powell was well and truly inoculated with air fever. In June 1880 a Commander Cheyne, late of the Royal Navy, who had a wide experience of Arctic expeditions, read a paper before the Aeronautical Society that received great publicity. He put forward a scheme for going to the North Pole by balloon.
\end{abstract}

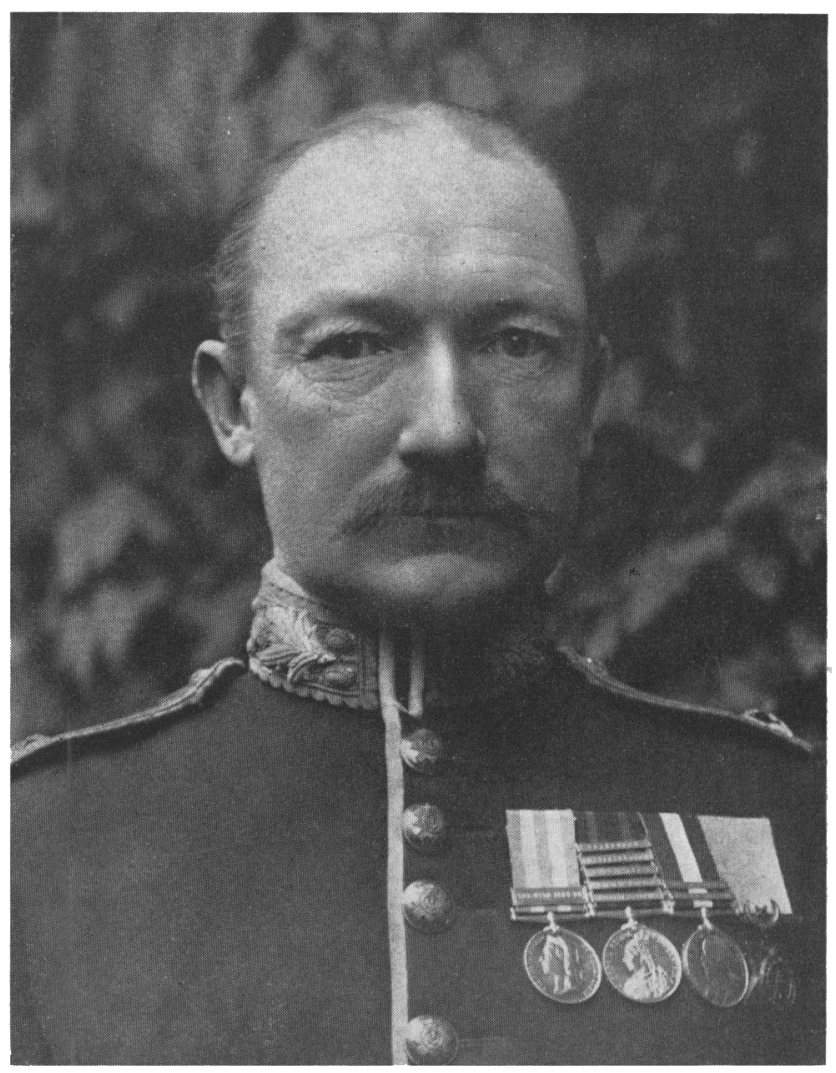

B. F. S. BADEN-POWELL

"Several ascents were organised with the idea of testing the suitability of balloons for Arctic use," records Baden-Powell, who was himself now taking a very lively and active interest in balloons, " and during this boom 'The Balloon Society' was started. In 1881 the subject began to grow in interest, military ballooning 
was for the first time in England being developed, and Captain Templer was making a name for himself."

Captain Templer had recently been appointed one of the organisers of the newly-formed Army Balloon School. He did much for military ballooning as well as for the development of man-lifting kites and for the first British Army airship, which was flown by Colonel Capper and S. F. Cody in 1907. Templer was a member of Council for the years 1881 to 1896 , and was one of those members who helped to save the Society from extinction on the death of Brearey, the first Secretary.

"The Balloon Society," recalled Baden-Powell, "determined to give a Balloon Garden Party at Lillie Bridge in 1881, and hired Simmons, the professional aeronaut, to make an ascent in his new indiarubber balloon."

The Balloon Society set an example which was followed successfully by the Aeronautical Society nearly seventy years later. There were great rivalries between the two bodies for some years. Baden-Powell was a member of both. In his life he was a supporter of most of the bodies formed to encourage any particular aspect of aeronautics.

"I at once secured a place in the car, and was early on the scene," continued Baden-Powell. Not only was he early on the scene, but he was so thrilled by his experience that he afterwards bought a balloon for himself, and made many trips in it, as well as taking up his friends.

In 1882 he joined the Scots Guards. Few army subalterns in those days were actively interested in anything so far-fetched as a possible war in the air. From very early days, though, Baden-Powell was convinced that the country which held the mastery of the air would be master of the world.

He came from an adventurous and inquiring stock. His mother was descended from that great Elizabethan adventurer, Captain John Smith, the first Governor of Virginia. His father, a Professor at Oxford, suggested small balloons for scientific use with the fatal Arctic expedition of Sir John Franklin, so Baden-Powell was

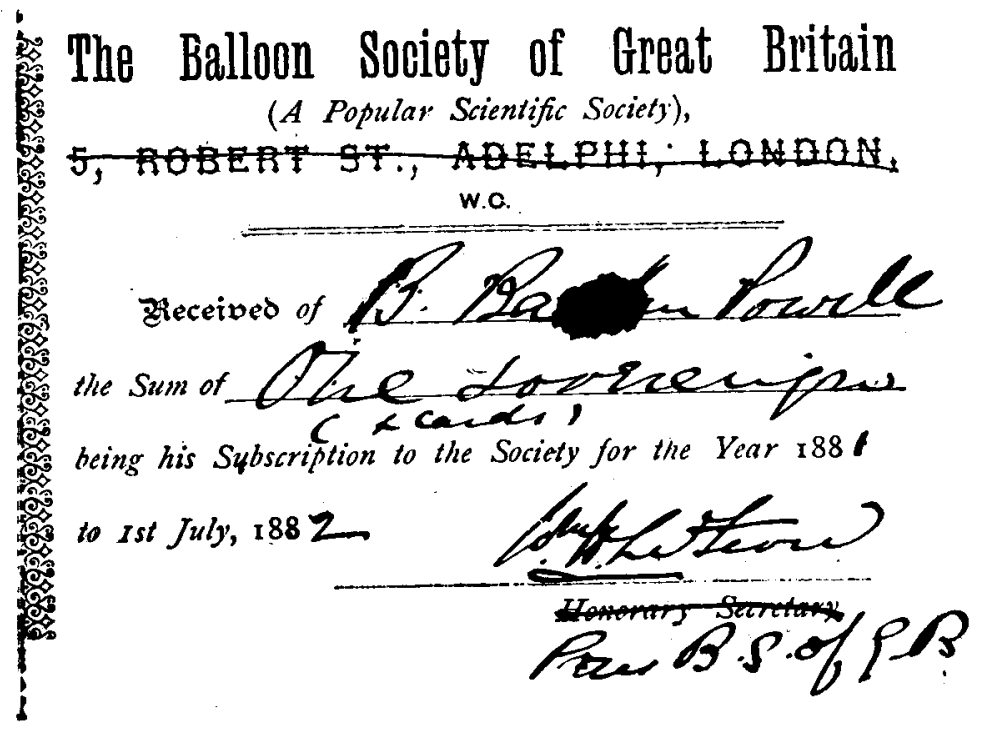

\author{
Balloon Society of Great Britain, \\ (.) POPULAR SCIENTIFIC SOCIETY.) \\ ANNUAL SUbSCRJPTION-FIVE SisILINGS. \\ OFEICES:-26, BUDGE ROIF, CANNON STREET, E.C. \\ W. H. LE. FEVRE, C.E., President. \\ LiLlie Bridge Grounds, WeST BRompton. \\ The President and Council of the Society request the pleasure of secing \\ B Baden Powtl
}

透

On Saturday Afternoon, the $30^{\prime}$ Jwly at 3 o'clock.

NOTE.-Genllemen and Ladies desiring to become Members of the Society, are invited to

Major Baden-Powell's invitation to the Balloon Garden Party and (below left) his receipt for his subscription to the Balloon Society for the year 1881-2-the days of the golden sovereign!

early put on the far from straight and narrow path of aeronautical navigation.

As a regular soldier he put the chief value of the conquest of the air as a military one. The year he joined the Army found him taking part in a vigorous public discussion on the dangers of ballooning, which he blamed largely on the carelessness of organisers and pilots. The following year, 1883, at the brave and confident age of 23, Baden-Powell lectured before the Royal United Services Institution on Military Ballooning.

The years 1882 and 1883 were indeed full of excitement for the adventurous and inquiring young subaltern. Of those years he wrote,

"In 1882 Colonel Burnaby*, who had already done a good deal in the aeronautical line, and was on the Council of the Aeronautical Society, succeeded in crossing the Channel in a balloon. This created further interest in the subject. Sir Claude Crespigny hired Mr. Simmon's balloon to attempt a similar feat, but an unfortunate accident at the start, in a violent wind, resulted in a broken leg and other injuries to Sir Claude, and Mr. Simmons was shot off in the air by himself. A remarkable Channel crossing was the result, for the aeronaut stated that it only took him twelve minutes to go from coast to coast! This would imply a rate fully two miles a minute, or 120 m.p.h!"

Hurricane Hazel must have read Baden-Powell's note about that Channel trip!

One must give Baden-Powell a considerable amount of praise for his nerve to face a military audience to lecture on military matters when he had only been in the Army a year. As it turned out the lecture was an able one, at a time when it was not the orthodox view to believe there was much in the air where the Army was concerned. And unorthodox views were no more popular than they are nowadays. His historical survey of military ballooning up to the date of his lecture,

*Famous for his ride across Russian Asia on horseback, described in his book $A$ Ride to Khiva. 
1st June, 1883, shows that he had read widely and profitably. In his introductory remarks he boldly declared, "It seems surprising that a body of aeronauts does not form a regular branch of every civilized army."

He lectured in the centenary year of the invention of the balloon and promptly rubbed it into his listeners that only ten years after Montgolfier had sent the first hot air balloon into the sky, the French had begun aeronautical research at Meudon and that the following year a regular balloon corps was formed.

"In October 1795, an aeronautic school was established at Meudon, composed of sixty pupils, who were instructed in all details of the construction and management of balloons as well as in all scientific subjects relating thereto.'

It was not until July 1862 , pointed out BadenPowell, that " the first military balloon experiments in England took place at Aldershot." Nine years later, in June 1871, a Committee was appointed to enquire into the use of balloons in warfare, although it was not until 1879 that an official Balloon Committee was appointed to carry out experiments.

Baden-Powell seized every opportunity of going to see anything which could go up in the air. The French had long been experimenting with dirigibles. Before his lecture he had gone over to Paris to see the airship of the brothers Tissandier, so that he could report on it. The following year he was back again in France to see the fish-shaped "La France" of the French Army at Meudon, the experiments with which are very fully described in the Annual Report of the Society for 1885 .

This trip to Meudon roused an interest which BadenPowell never lost. In later years he lectured and wrote papers on the subject and visited Germany, France and the United States to see airships. I have before me a brief tabulated record of a few of his visits.

“ In 1899 went to Friedrichshafen and spent two days going carefully over the Zeppelin Works and watching the construction of No. 1 Zep.

“ 1903 went to Paris to see Santos Dumont's airships. Also went over the Lebaudy works.

"Went to United States and the St. Louis Exposition, 1904, where about four different airships were tried.

"Watched all the developments of the Barton airship; also the Spencer (fitted with an engine designed by Baden-Powell). Saw the original Willows airship at Cardiff.

" 1909 went to Frankfurt Aeronautical Exhibition, where the 'Parseval' made daily ascents. Visited the aviation meeting at Rheims, where the 'Col. Renard' and 'Zodiac' airships made ascents.

" 1912 to Berlin Aero Exhibition, and to Bitterfeld and over the Parseval works."

These names mean little to a modern generation totally unaware of the real delights of airships. I have always believed, and indeed still defiantly believe, that a cruise in an airship can beat anything the aeroplane can offer, scenery, entertainment, quiet, comfort. Baden-Powell was enthusiastic enough to design a model dirigible, 40 feet in length, filled with hydrogen, in later years. It was driven by a model engine.

His trip to France in the late summer of 1884 was his last sight of an airship for some time, for he was really jolted down to earth by being sent by the War Office to take part in the Nile Campaign, riding a camel!

Late in 1886 he was elected a member of Council of the Society, its youngest member. There is an interesting letter from Brearey, the first Honorary Secretary of the Society, written to Baden-Powell at the beginning of this year.

"I have had no occasion since I wrote to you, to call the Council together-or rather since I received your letter of consent," wrote Brearey. "My present note is to inform you that on the 12th January is the 20th anniversary of the Society, which was instituted at a meeting at the Duke of Argyll's, and that I have made a proposition that we mark the event by a dinner."

This year we celebrate the 90th anniversary. I have always hoped that 12 th January would be celebrated annually by some function open to all members, something to which they could look forward, which would symbolise, too, that they belonged to the pioneer Society of the Air Age. I had always hoped, too, that it would be the day when the President would review the past year's work of the Council and its Committees, and tell of the achievements by the Society's members; when he would outline the achievements yet to come, the paths of research yet to be trod, and hold out "Every Tomorrow a Vision of Hope." But somehow the hope has not fructified.

It was, by the way, at the 1886 Annual Meeting of the Society that Captain Griffiths' paper, "Jet propulsion for aeronautical purposes," was read.

Although asked by the Council to read a paper at the next meeting of the Society, Baden-Powell was for the next few years as far removed from the Society as it was possible to be. He went to Queensland, Australia, as A.D.C. to the Governor, during which time he campaigned in New Guinea and travelled in Java and Borneo. The result of these years was his book, In Savage Isles and Settled Lands, bearing the formidable subtitle, "A personal record of personal experiences in Europe, Egypt, Ceylon, India, Australia, New Zealand, New Guinea, Java, Straits Settlements, Borneo, Tonga, Samoa, Sandwich Isles and the United States."

Before he left England Baden-Powell had begun inquiries into the possibilities of lifting a man into the air by means of kites. He wrote to Henry Coxwell, who, with James Glaisher held the world's height record for more years than any others have ever done, suggesting that kites might be substituted for captive balloons for military purposes by raising an observer into the air.

In 1894 he carried out the successful trial trip of the Army war balloon, the "Duchess of Connaught," from 


12 VOL. 60 JOURNAL OF THE ROYAL AERONAUTICAL SOCIETY
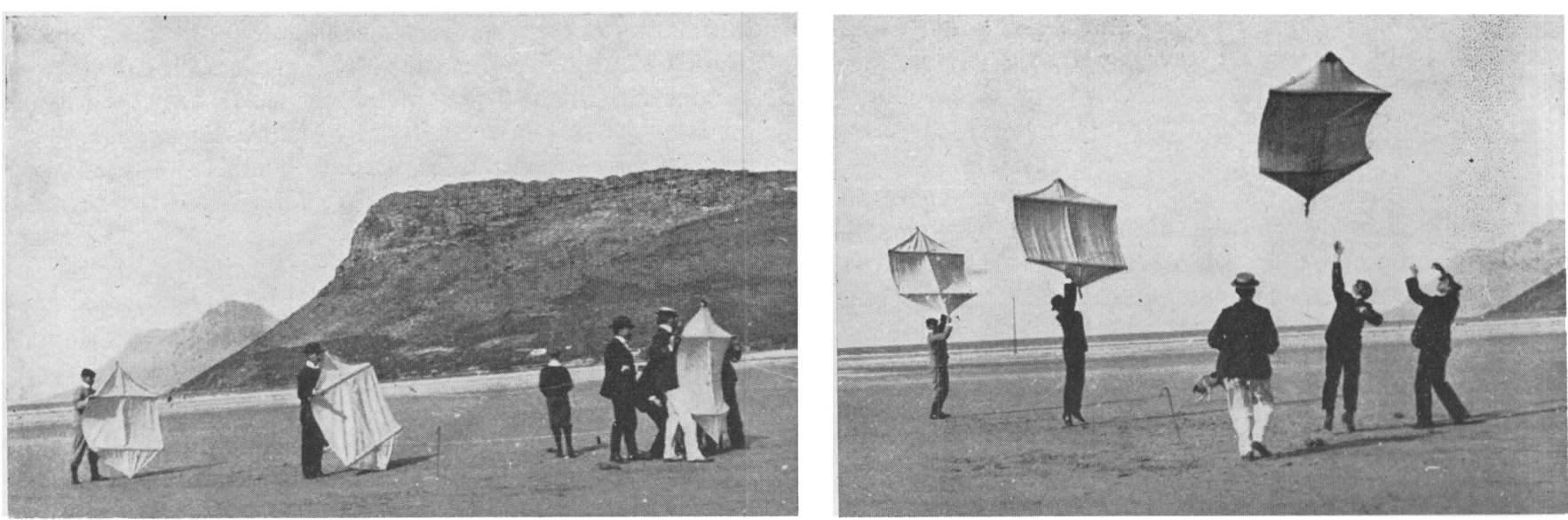

The method of starting the Baden - Powell man - lifting kites.

Aldershot, and then seriously turned his attention to the kite problem. At his home at Pirbright it is recorded in the Aeronautical Journal for April 1897, in a paper on Man-lifting war kites, "The first wellauthenticated occasion on which a man was raised by a kite was on January 27, 1894 when Captain BadenPowell, Scots Guards, conducted some experiments at Pirbright Camp with a huge kite 36 feet high." This kite had a lifting surface of some $500 \mathrm{sq}$. $\mathrm{ft}$.

By May 1895 he felt that he knew enough to lecture on the subject to the Royal United Service Institution. He asked Lord Methuen* to take the Chair. Methuen replied "I am quite ready to take the Chair on the 22nd, and recommend anyone, except myself, to go up with your kites."

It was Lord Methuen who said of the R.U.S.I. at Baden-Powell's lecture,

"If it has any claim on the Army and Navy, and it has a very great claim, it has none so great as this, that every fad and every invention can be brought forward here by military and naval officers alike; that they can put forward their inventions, they can have them discussed by naval, military, and civilian alike, and that they will get a good and patient hearing; and many an invention, which is quite in its childhood, has gained its existence simply from being well argued in institutions such as this."

Baden-Powell's child of the air received a rough reception from the balloonatics, for he had asserted with great confidence that the kite would replace the balloon for observation purposes, and that would never do, for it would have put balloon enthusiasts out of their jobs.

The first speaker, Lt. R. B. Blakeney, of the Balloon Section of the Army, certainly couldn't agree. The second speaker roundly declared, "I made a great many experiments with kites during last summer, and thought the matter over to a certain extent during the winter, and I have come to the conclusion that there is not much in it."

*Joined Scots Guards 1864, commanded Methuen's Horse in Bechuanaland Expedition 1884-85; commanded 1st 'Army Division in Boer war, etc, and became a Field-Marshal in 1911.
In fact all the speakers disagreed with the lecturer and Lord Methuen wound up the proceedings by saying, in no uncertain terms, that he wasn't satisfied as to the safety of kites.

Baden-Powell was not easily put off by uncomplimentary criticisms. He had plenty of that during his life, when he put forward ideas. That September he demonstrated his kites before the meeting of the British Association at Ipswich.

"The weather was not very favourable for an ascent, the breeze being of the lightest description," reported The Times. "Nevertheless, Lieutenant Baden-Powell and subsequently two other individuals were easily raised to a height of some $50 \mathrm{ft}$."

Later in the year Baden-Powell went up over $100 \mathrm{ft}$., and in a paper in the National Review for December 1895 he vigorously championed afresh the use of kites for observation purposes. The previous autumn he had kept a weight of 9 stone flying all day long at Pirbright camp, at a height of $300 \mathrm{ft}$. When he lectured before the Society of Arts in 1898, he had a more appreciative audience.

Brearey had died at the beginning of 1896 and it looked very much as though the Society would cease

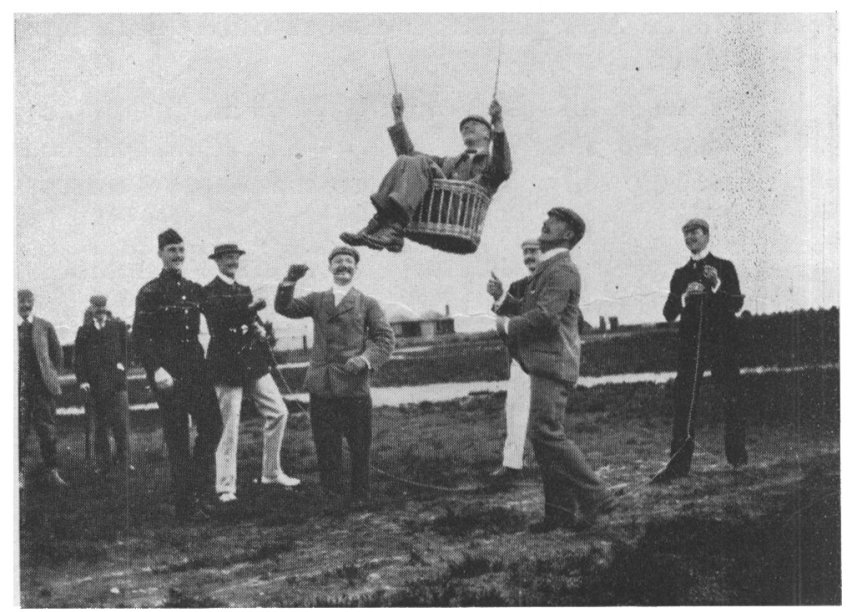

The first man - lifting experiments. 
to exist, for the membership was almost a negligible quantity, not a couple of score altogether. Brearey had always been convinced success would come and it was his constant thought to keep the Society going, however few the stalwarts were. He had approached several members to take over his papers and Society material in case of his death, and they were duly sent to E. A. Barry, one of the senior members of the Council. Late in 1896 Barry managed to get together a meeting of the Council.

It was a thin meeting. Besides Barry there were present only Baden-Powell and E. P. Frost (who afterwards became President). Six members of the Council out of the eleven listed at the death of Brearey, had sent in letters of resignation! There was only $£ 55 \mathrm{~s} .0 \mathrm{~d}$. in the kitty. At this meeting of the dauntless three, one proposed, one seconded, that the third, Baden-Powell, should be asked to act as Honorary Secretary and keep the bridge between the aeronautical past and the future.

Baden-Powell accepted the challenge and for that inspired decision of hope alone, he deserves a special place in the long history of the Society.

He called a meeting at his own house twenty days later, and announced that Hiram Maxim, Major J. D. Fullerton and Sir Edwin Arnold had agreed to serve on the Council. He explained that he had written to many of the leading scientists and prominent people suggesting they should join the Society. One answer which he received is produced facsimile, for it is a classic. It is dated 8th December, 1896, just seven years before the Wright Brothers made their first flight. It reads,

"Dear Baden-Powell, I am afraid I am not in the flight for 'aerial navigation.' I was greatly interested in your work with kites but I have not the smallest molecule of faith in aerial navigation other than ballooning or of expectation of good results from any of the trials we hear of. So you will understand that I would not care to be a member of the Aeronautical Society. Yours truly, Kelvin."

Baden-Powell was then writing his paper "The Conquest of the Air," which was to be published in the April 1897 issue of the Royal United Services Magazine. It gives a different point of view and provides its own comment.

"The object of this article is to show that aerial navigation is now no mere wild dream, but will very probably form a prominent feature in the next great war ... What will the good citizens of London say when they see a hostile dynamite-carrying aerostat hovering over St. Pauls? Our naval supremacy would be comparatively useless if we had no aerial force. It therefore becomes not only desirable for us to have aerial machines for offence, but it becomes necessary for us to possess them for defence against hostile attack through the air, and the speediest and handiest machine will win the day."

At the December 1896 meeting of the Council, when only four members were present, Messrs. Roberts, Frost, Barry, and Baden-Powell, it was resolved that a quarterly Journal should be issued. In a letter to Lt.

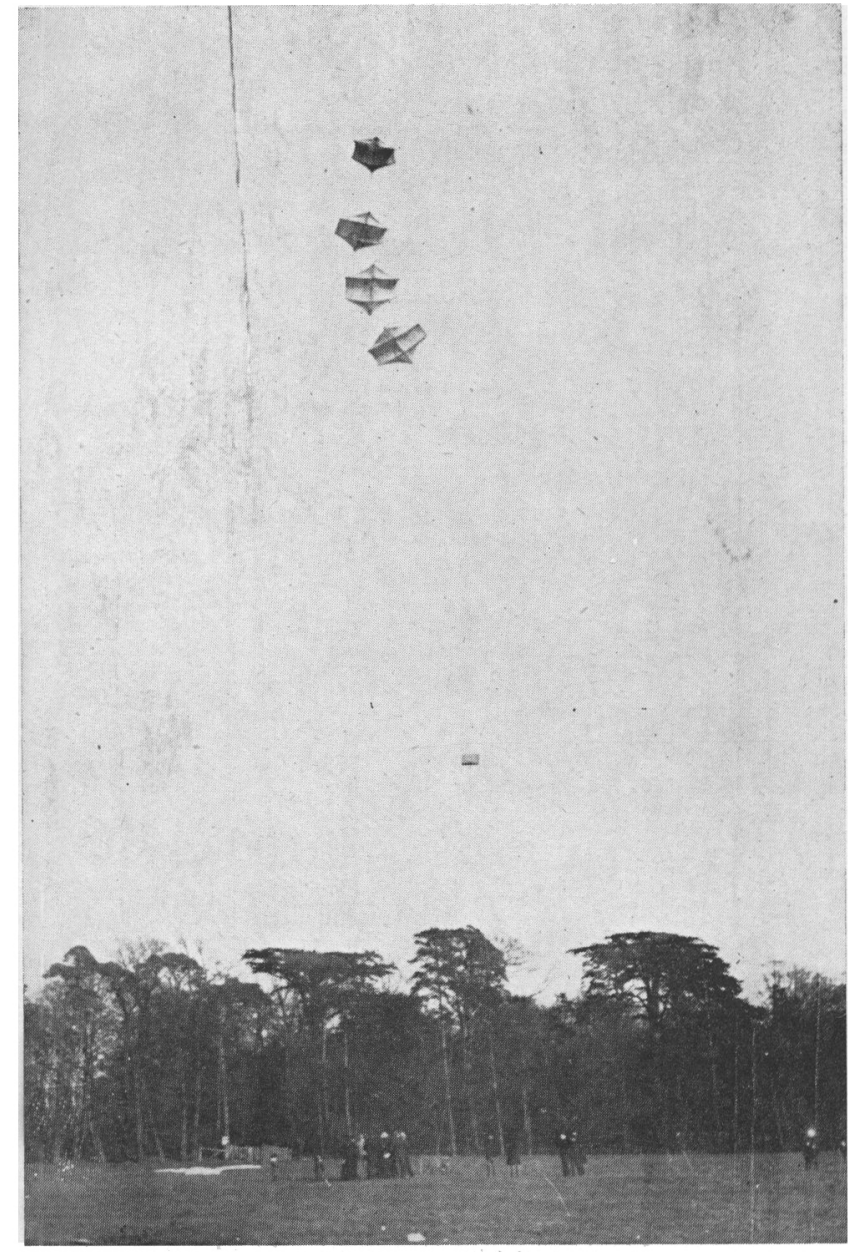

A man being lifted at Aldershot in 1895 by Baden - Powell's kites.

Colonel Lockwood Marsh, Secretary of the Society, on 5th February 1923, Baden-Powell wrote,

"It may interest you to know how it started. When we resuscitated the Society we suggested publishing some sort of Journal-to continue the Reports-but there was only about half a dozen members and no money. So we discussed ways and means, and it was suggested that some of us should subscribe together to bring out a Journal, but this should be a private affair and the Society should not be saddled with the expense of it. I think we also hoped that in time we might recoup ourselves. . . . However, of course, it never paid and gradually it drifted into becoming the property of the Society. But that is why we did not call it The Transactions or any such title. We called it the Aeronautical Journal in imitation of the Geographical Journal. But these things are soon forgotten."

At the March 1897 meeting the Hon. Secretary reported a balance of $£ 15$ and a membership of 39 , including four non-paying honorary members. The annual subscription still remained at one guinea, as it had been from 1866. An extract from the March Council meeting reads, 
14 VOL. 60

JOURNAL OF THE ROYAL AERONAUTICAL SOCIETY

JANUARY 1956

sinallest molecule of faith in acre al navigation otter than viallooinizor of expectate of Hood rule riv k any it the trials we hear fo you url under hand that / word not care te a number of the ain nautical Society. Yours truly Kelvin

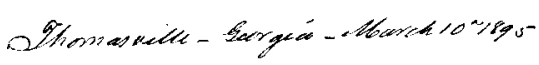

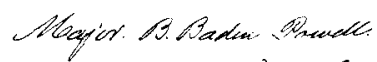
Hey dear sion.

S cons spending of uaw cued

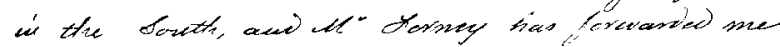

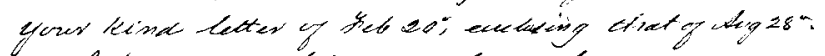

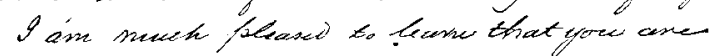

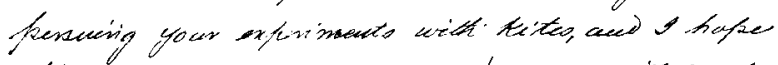
thick as bow as grow are really grow with wonder

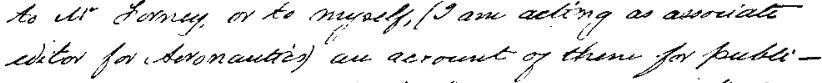
cation. How will find in spencer bingincen" for

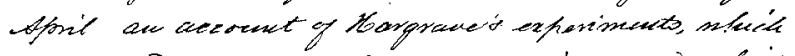

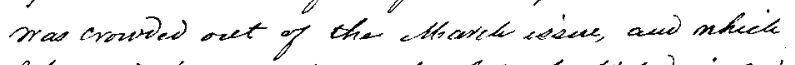

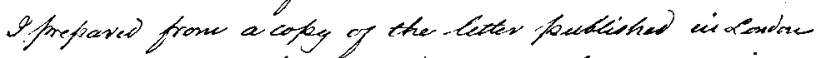
Engineering for hel is. I fancy that a frei

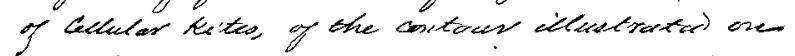

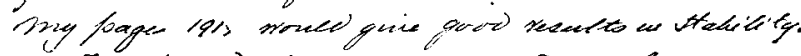

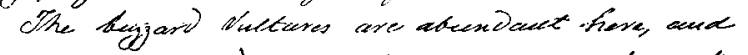

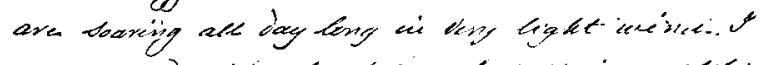

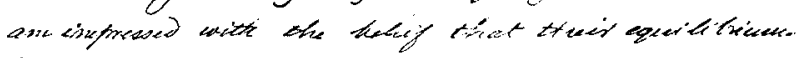

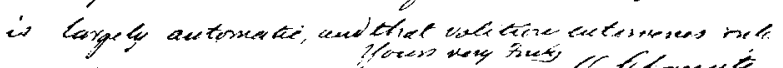

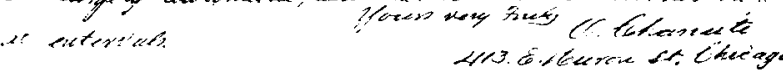

$\operatorname{Dec} 8 / 96$ THE UNIVERSITY, GLASGOW.

Dear Baden Powell I an of raid am not in the flifletro " areal" nacrifali ni.' I was prats intenerate in your work wite kites: b. Wave not the

(Above): Lord Kelvin's reply to Major Baden-Powell's invitaion to join the Aeronautical Society (half size). (See p. 13.) (Left): A letter from Octave Chanute which reads:

Thomasville - Georgia - March 10, 1895

Major B. Baden-Powell My dear Sir,

I am spending a few weeks in the South and $\mathrm{Mr}$. Forney has forwarded me your kind letter of February 20th enclosing that of August 28th

I am much pleased to learn that you are pursuing your (notes, and I hope that as soon as you are ready you will send to Mr. Forney or myself (I am acting as associate editor for Aeronautics) an account of them for publiaccount of Margrave's experiments, which was crowded out of the March issue and which I prepared from a copy of the letter published in London Engineering for Feb. 15. I fancy that a pair of cellular kites, of the contour illustrated on my page 191 would give good results in stability.

The buzzard vultures are abundant here, and are soaring all day long in very light winds. I am impressed with the belief that their equilibrium is largely automatic and that volition
enters only at intervals.

Yours very truly,

O. Chanute.

413 E. Huron St., Chicago.

https://doi.org/10.1017/S0368393100132377 Published online by Cambridge University Press 


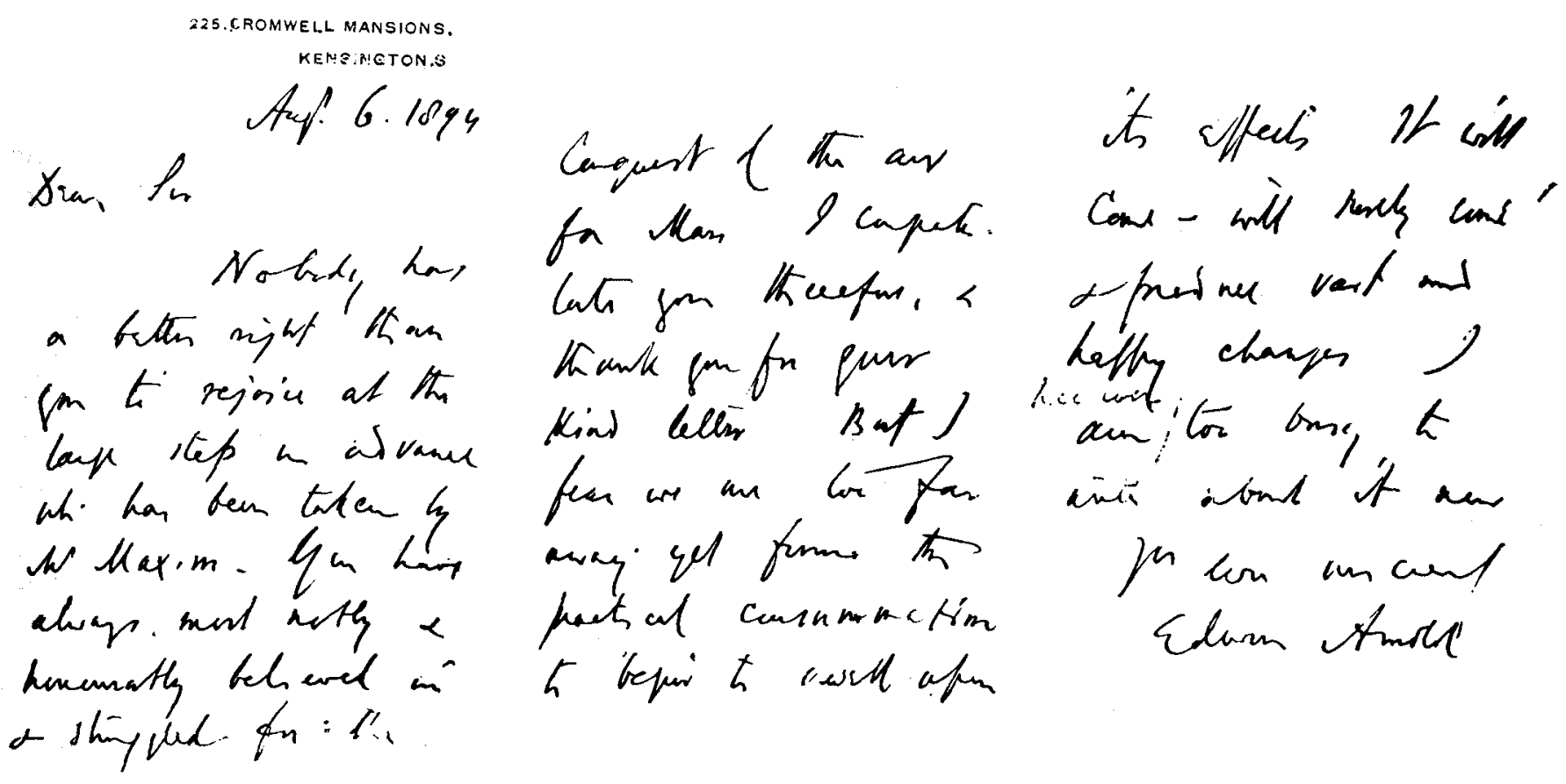

A letter from Sir Edwin Arnold, dated 6th August 1894, to Major Baden-Powell, which reads:-

“Dear Sir,

Nobody has a better right than you to rejoice at the large step in advance which has been taken by Mr. Maxim. You have always most nobly and honourably believed in and struggled for the Conquest of the air for Man. I congratulate you therefore and thank you for your kind letter. But I fear we are too far away yet from the practical consummation to begin to dwell upon its effects. It will come-will surely come! and produce vast and happy changes. I am however too busy to write about it now.

Yours ever sincerely,

Edwin Arnold."

(Sir Edwin Arnold became famous for his epic poem The Light of Asia. He was a schoolmaster in India, returned to England and became editor of The Daily Telegraph).

"The Society did not possess sufficient funds to provide a suitable quarterly Journal without outside support. However the Honorary Secretary suggested issuing the Journal entirely at his own expense and risk."

For the first three years, indeed, Baden-Powell bore the greater part of the burden of the Journal. It may be of interest to quote actual figures. On a scrap of paper found among Baden-Powell's papers he had made rough notes summarising the finances of the Journal from 1897 to 1899 . The usual number of copies printed was 300 . The total cost for those years was £211 7s. 3d. and the total receipts $£ 7215 \mathrm{~s}$. $6 \mathrm{~d}$. The Council voted $£ 48$ toward the cost over the years, leaving the rest to be paid privately. Of it Baden-Powell contributed the largest portion.

Today the number printed of the Journal is 9,750 and the receipts and expenditure accounts are published for all to see.

On receiving the first number of the Aeronautical Journal the Editor of Invention wrote an article which I would have liked to have quoted in full. He had been the Editor for many years of the famous Mechanics Magazine to which Sir George Cayley and many others had contributed on the subject of aerial navigation.
He had known all those who had first joined the Society in 1866 and for the first five years or so of its existence he had regularly recorded its proceedings.

"A copy of the first number of the new issue of the Aeronautical Journal," he wrote, "carried us back only a generation, to the time when the Aeronautical Society was a power in the land; when it had a good practical Council, good meetings, good papers, good exhibitions, in fact, when all was sound and substantial about it. But it retrograded, languished, pined, and all but resolved itself into a mere memory of the past."

In 1899 Baden-Powell sailed for South Africa on the outbreak of the Boer War, and E. S. Bruce became the Honorary Secretary.

" The Council whilst accepting with regret the resignation of Major Baden-Powell take the opportunity of recording the very valuable services rendered by him to the Society, which he virtually re-established from the time he accepted the Honorary Secretaryship by his inaugurating the new quarterly Aeronautical Journal."

Bruce had been asked by Brearey to take on his work after his death. 


$$
\begin{aligned}
& \text { The Beacon Goldowor } \\
& \text { Wothing Rarry } 30 \text { Cop. } 1899
\end{aligned}
$$

Hean sin pours of ferterdays diste carne

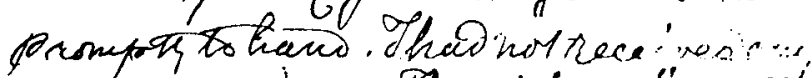

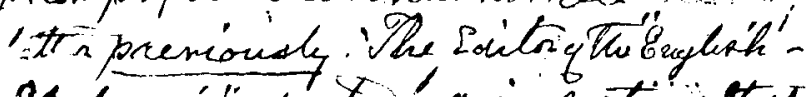

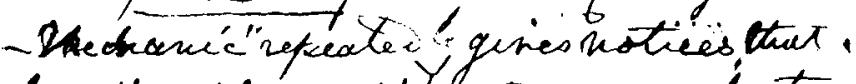
be inll not forwand litterpto cosrespondents,

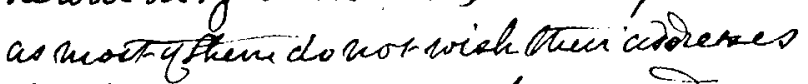
tone kutwn-4ithe $\mathrm{S}$. may be ef cined Ievery anch appreceiate the cousederate

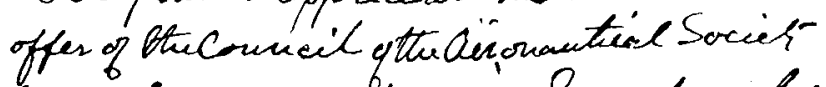

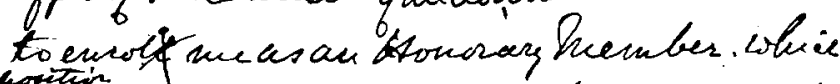

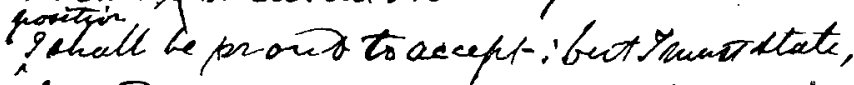

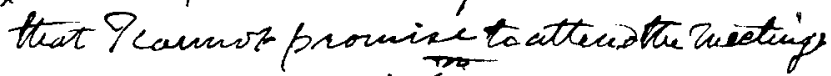
ar 9 un now in the $y$ beat of ney age.". but Thave not lodiuterast in deronanties

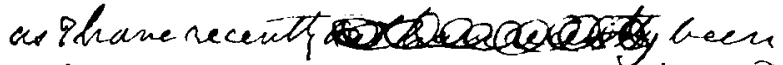

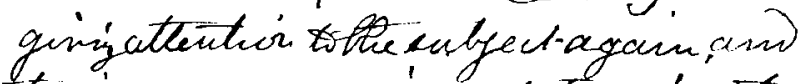
truging concestherinent. Lcuding to

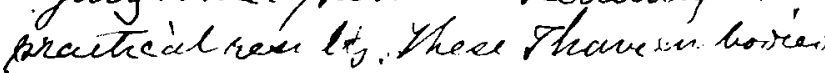
in a pupes whic 2 had come thonghts of

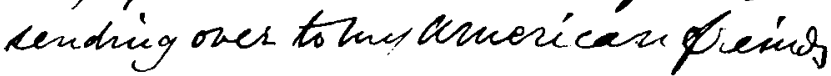

A letter from F. H. Wenham which reads:-

The Beacon Goldsworth Woking, Surrey, 30th Sep. 1899

“ To Major Baden - Powell Dear Sir,

Yours of yesterday's date came promptly to hand. I had not received any letter previously. The Editor of the English Mechanic repeatedly gives notices that he will not forward letters to correspondents as most of them do not wish their addresses to be known - so the Ed. may be excused.

I very much appreciate the considerate offer of the Council of the Aeronautical Society to enrol me as an Honorary Member, which position I shall be proud to accept: but I must state, that I cannot promise to attend the Meetings as I am now in the 76th year of my age, but I have not lost interest in aeronautics as $I$ have recently been giving attention to the subject again, and trying some experiments tending to practical results. These I have embodied in a paper which I had some thoughts of sending over to my American friends. Do you now publish periodical reports? as I do not wish what I have written to be shelved.
Do grumow publich poriadeciel tepont? as

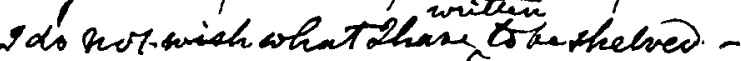

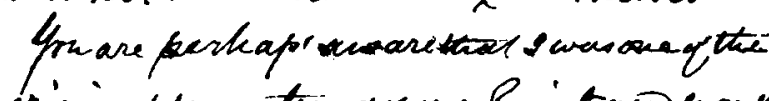

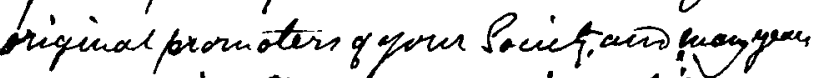

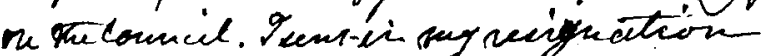

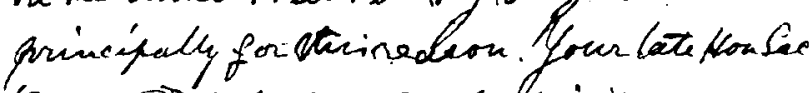

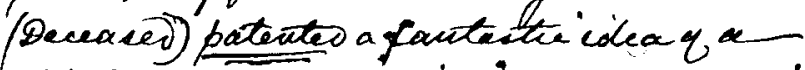

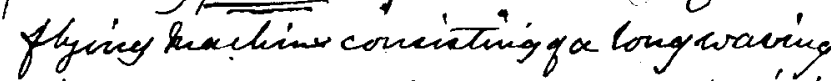

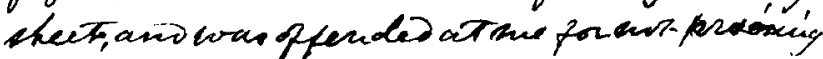
is an being the right thing fon encrsing teltivita

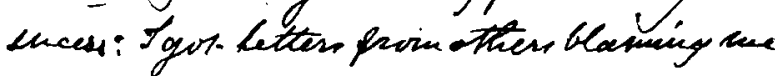
for mot condevweig the tetwene and to

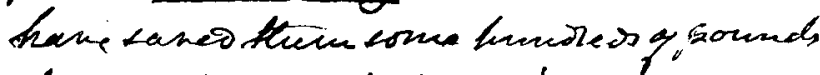

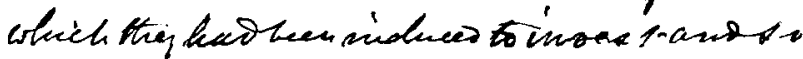

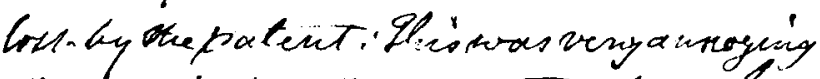
stme exfeciaty as there were the at of a low.

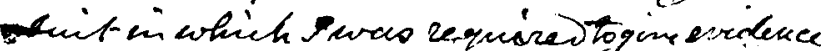

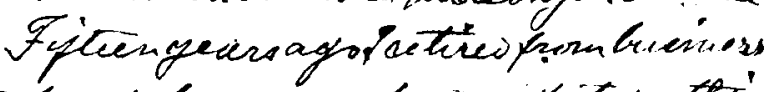

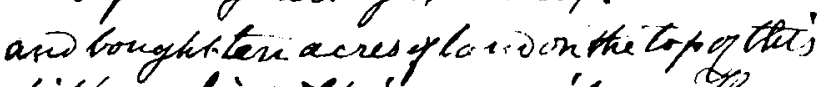
hill, on which Ybuils-a reverdence thespots wout cerac for agleding flight, butis co worted with carge trees anvevengreens

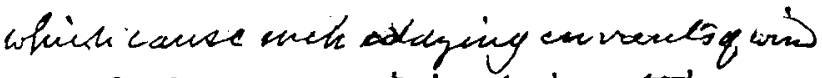

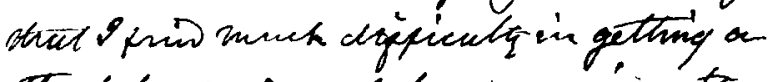
Dexoly lrevise on out don esperemients

$$
\begin{aligned}
& \text { Taittuly ouns } \\
& \text { I. H. Herehour }
\end{aligned}
$$

You are perhaps aware that I was one of the original promoters of your Society and many years on the Council. I sent in my resignation principally for this reason. Your late Hon. Sec. (deceased) patented a fantastic idea of a flying machine consisting of a long waving sheet, and was offended at me for not praising it as being the right thing for ensuring ultimate success. I got letters from others blaming me for not condemning the scheme and so have saved them some hundreds of pounds which they had been induced to invest and so lost by the patent. This was very annoying to me especially as there were threats of a law suit in which I was required to give evidence.

Fifteen years ago I retired from business and bought ten acres of land on the top of this hill, on which I built a residence. The spot would serve for a gliding flight, but is so wooded with large trees and evergreens which cause such eddying currents of wind that $I$ find much difficulty in getting a steady breeze for outdoor experiments.

Faithfully yours F. H. Wenham." 
"At that time I did not see my way to undertake so serious a duty," declared Bruce in an account of the Society which he gave to La Société Francaise de Navigation Aerienne de Paris in 1900. "Shortly after Brearey's death the Council asked Major Baden-Powell to accept the post and with the energy characteristic of the Baden-Powell family he rapidly infused new life into the Society, increased the quantity and quality of its members, enlarged the Council and developed the quarterly Journal."

In South Africa he had little opportunity to follow his aeronautical interests, although it is recorded that some use was made of his man-lifting kites for raising Marconi wireless apparatus. He had followed the work of Marconi very closely and spent much time with him during his early experiments. The smug comment of one of the newspapers was " The services rendered by Major Baden-Powell illustrate how useful it is for a British officer to have a hobby in peace time of more practical value than polo or billiards."

While still in South Africa he was elected President of the Society and on his return to England became very active again in the aeronautical world. On 4th December 1902 he gave his Presidential address to the Society on "Recent Aeronautical Progress." Two days before he had taken the Chair at the Council, when it was announced that for the first time in its history the Society was renting an office of its own and was starting a library for the use of its members. The membership had risen to 100 and the balance in the Bank was $£ 204$.

Baden-Powell's Presidential address has been widely and often quoted, and was reprinted by the Smithsonian Institution in Washington. He told his hearers of the work of Lawrence Hargrave in Australia; of that of the Wright Brothers, and Chanute and Samuel Langley in the United States of America; of the dirigibles of Zeppelin, Santos-Dumont and others; and surveyed the progress while he had been away in general terms. He left his hearers with the confident hope that the air age was only just a little time ahead. Twelve months later, indeed, that confident hope was fulfilled.

He spoke of the Society and its future, words which still stand.

"I may here seize the opportunity of explaining to our visitors and others the objects of our society, and why it is we make so much of a study which to them may seem somewhat chimerical and of no very special merit, and by explaining these I hope to enlist their sympathy and support to the movement. For I have before now been asked "Why should it be necessary to have a society for the study of aerial navigation? Where is the importance of it? Why not institute a society for submarine navigation, for wireless telegraphy, or for the encouragement of any other novel invention for the improvement of means of communication or warfare?' But useful as many such inventions may be, none can have the great importance which may some day be attached to the machine which navigates the air. ...

"We have to study the subject of aerodynamics, the effect of air pressures on plane or curved surfaces travelling at various speeds and at various angles of incidence. We have to investigate the efficiency of aerial propellers of different forms, the strengths of materials, the energy and weights of various forms of motors. Then we must also study the natural currents of air, the variability of air strata, the trends of winds and so on. The great range of subjects to be gone into by our Society is thus patent."

Baden-Powell was the first to announce the recent progress of the Wright Brothers and he did'so in this address, in convincing detail.

"I received a letter only a few days ago from $\mathrm{Mr}$. Chanute," he said. "He says that he had just returned from witnessing this season's gliding experiments of the Brothers' Wright and that they have made a very considerable advance since last year, and now glide at angles of $6^{\circ}$ to $7^{\circ}$ sustaining 125 to 160 lb. per horsepower. Wright is now doing nearly as well as the vulture, is not far from soaring flight, and I am changing my views as to the advisability of applying a motor."

What a thrill those words must have given many of those present, coming with all the authority of their own President and Octave Chanute, whose own experiments had been attracting much attention. In the Journal for December 1953 there was printed a facsimile of the attendance sheet, and there can be seen the signatures of Hiram Maxim, Griffith Brewer, E. P. Frost (later President of the Society), Patrick Alexander, Alec Ogilvie, C. S. Rolls and many others.

Baden-Powell not only wrote to many aeronauticallyminded people, but went to see what they were doing. He was one of the witnesses of the work of Horatio Phillips with his remarkable venetian blind machine; of Maxim and his great machine at Baldwyn's Park; of Pilcher and his gliding experiments. He was unhappily present when Pilcher had his fatal accident. He watched Zeppelin fly in his first dirigible and saw the flights of the French Lebaudy and Santos Dumont dirigibles. He saw the early flying in France, flew himself with Wilbur Wright, went to the great Rheims meeting and the many meetings in England.

He received a disappointing setback about his manlifting kites. S. F. Cody had been experimenting for some years, was a far greater showman of his wares, and the War Office finally decided in favour of his kites. Cody patented his form of construction in 1901, seven years after Baden-Powell had lifted himself 30 feet in the air with one of his own kites, and Cody's biographer, G. A. Broomfield, wrote, "The design had possibly been influenced by the work of Hargrave and Major B. F. S. Baden-Powell."

In 1904 Baden-Powell made some interesting experiments in gliding technique, for he had come to the conclusion that the simplest way to gain initial gliding speed with safety was to launch his glider down an inclined track finishing over a sheet of water.

The Crystal Palace authorities allowed him to build a water chute at the edge of one of the lakes in the Palace grounds. The glider consisted of a flat-bottomed 


18 VOL. 60 JOURNAL OF THE ROYAL AERONAUTICAL SOCIETY
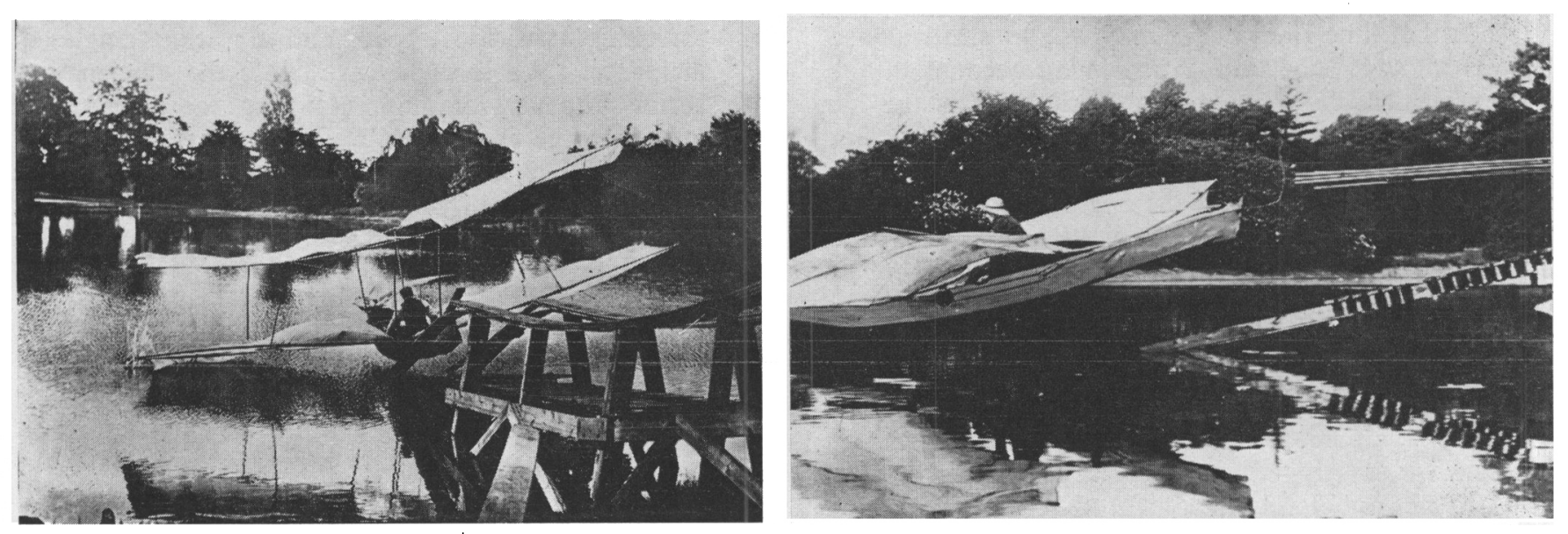

The gliding water-chute experiments at the Crystal Palace in 1904.

boat, about $20 \mathrm{ft}$. in length and $2 \frac{1}{2} \mathrm{ft}$. beam, which slid down on wooden rails. The boat was fitted with flexible wings, both biplane and monoplane, constructed with thin cambric stretched over a bamboo frame.

A number of glides were made, though none of them very long. Baden-Powell was helped by J. T. C. Moore-Brabazon (now Lord Brabazon of Tara). Maybe the latter was getting in some practice for the Cresta Run!

Later in the year, in a paper on "The Development of the Aeroplane," which he read before the British Association at their meeting in Cambridge, BadenPowell briefly described these interesting experiments which, however, did not reach any conclusive stage. The same year he designed and had constructed a light petrol engine for aeroplanes, which he exhibited at the St. Louis Exposition.

Baden-Powell was a born experimenter and was not deterred by failure. Hope sprang eternally in his breast. He was an example of "Man never is, but always to be blest" as far as aviation was concerned. He worked like a beaver at his ideas, hoping that out of the mass of figures he accumulated that he would be able to solve the great secret. The Society has a number of his notebooks which are filled with sketches of model gliders, of paper, wood and fabric, proposed aeroplanes and helicopters, ideas for airscrews, and notes of experiments made and those to be made. These notebooks provide mute evidence of the incredible industry of their owner, an industry worthy of a greater degree of success than he obtained. Like many experimenters of the time he was lacking the fundamental training and data which were essential for success, and hoped that by trial and error he would hit on the answer. With him, as with most experimenters like him, there was too little trial and too much error.

He missed no opportunity to lecture on aviation, to write papers on the subject, to write to all those interested and to many who were not. He filled his notebooks with data from all sources. When he lectured or wrote, he seldom failed to draw attention to the Society and the advantages of becoming a member of it.
This year, 1904, was one of great interest. In addition to his Crystal Palace experiments and his paper to the British Association, he visited the St. Louis Exposition, together with two of the leading members of the Society. It was the first official representation of the Society in the United States.

"Our Society was well represented," he reported. "Colonel Capper and Mr. Walter Reid both took a prominent part in the meetings of the Aeronautic Conference and also on the Jury in the Kite Competition."

All three damned the organisation of the Exposition, but all three learnt the great value of making such visits and learning what the other man was doing. Capper took the opportunity to visit the Wright Brothers, with whom he and Mrs. Capper became very friendly, and at the Society's meeting on 2nd December 1904 he said

"From the experience we gained we can all do a great deal more in the way of experimenting with gliding machines in this country than has been done ... I shall be very much surprised if we do not hear from America before long of a gliding machine driven through the air by a motor. I am not at liberty to give any details on the subject, but I shall not be surprised if we hear of that being practically done..."

In fact Capper was well aware of what the Wrights were doing for in a letter (25th November 1905) Orville Wright wrote to the British Military Attaché in the U.S.

"At the request of Lt. Colonel Capper we gave the British government the first chance to secure the use of our invention to foreign countries. . But the progress of the later negotiations has been such as to make it possible that a crisis will be reached before the British War Office has all the obtainable information before it and is ready to reach a decision as to whether it will take up the flying machine at this time."

Baden-Powell could not stop himself writing about aviation. For many years he was the Editor of Knowledge and Illustrated Scientific News. It did not pay its way, but Baden-Powell had many good friends, 
like Frank McClean and Dr. W. J. S. Lockyer, who encouraged him to keep going and showed their practical help by paying some of the bills. After he had failed to sell it to Pearsons in 1904 Baden-Powell had printed a supplement, Aeronautics and in 1907 issued it as a separate publication under the editorship of himself and J. H. Ledeboer. Unfortunately the aeronautical slump which followed the First World War was too severe for the pocket of its owner and it was closed down in 1921. But in Knowledge and in Aeronautics there is much recorded which might otherwise have been lost of those exciting and stimulating pioneering years.

On 4th August, 1908, Baden-Powell wrote to the War Office to say that he was constructing an aeroplane "which is now nearly ready for trial," and would they

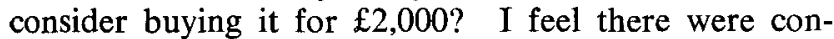
siderable streaks of naivety in his make-up.

The Director of Army Contracts replied by forwarding a copy of the specification for a Military Flying Machine, and of the tests and general conditions which would have to be fulfilled before the machine could be accepted and paid for. They are historic documents.

The letter from the War Office was dated 4th September 1908. The American contract with the Wrights was published nine months previously, on 23rd December 1907, as required by United States law, so the British War Office would have had a copy when it issued its own specification and tests to Baden-Powell.

The American contract agreed to pay $£ 5,000$ for any heavier-than-air machine capable of carrying two people weighing in aggregate $350 \mathrm{lb}$., with petrol sufficient for 125 miles, at a speed of 36 m.p.h. The issue of the contract was criticised severely in America, as the War Department was supposed to have lost its head! Fifteen days after the British War Office sent a copy of its specification to Baden-Powell, Orville Wright flew for 58 minutes at Washington. The date, 19th September, 1908.

The British Specification is given here in full.

\section{"SPECIFICATION FOR MILITARY FLYING MACHINE."}

1. The machine must have carrying capacity sufficient to carry

(a) Operator. Average weight $170 \mathrm{lb}$.

(b) Observer. Average weight $170 \mathrm{lb}$.

(c) Instruments, maps, etc. Average weight $10 \mathrm{lb}$.

(d) Fuel for a journey of four hours.

2. It must be capable of rising from or descending on to any fairly smooth ground of an area of 10 acres, without damage to itself or occupants.

3. It must have an average speed when in the air of not less than 25 miles an hour in a calm, which speed it shall maintain for not less than one hour.

4. It must be capable of rising with its full load to a height of 2,000 feet above its starting point, and be able to carry its full load at height of 5,000 feet above Mean Sea Level.

5. It must be reasonably steady when under flight, in order that observation with field glasses may be made from it.

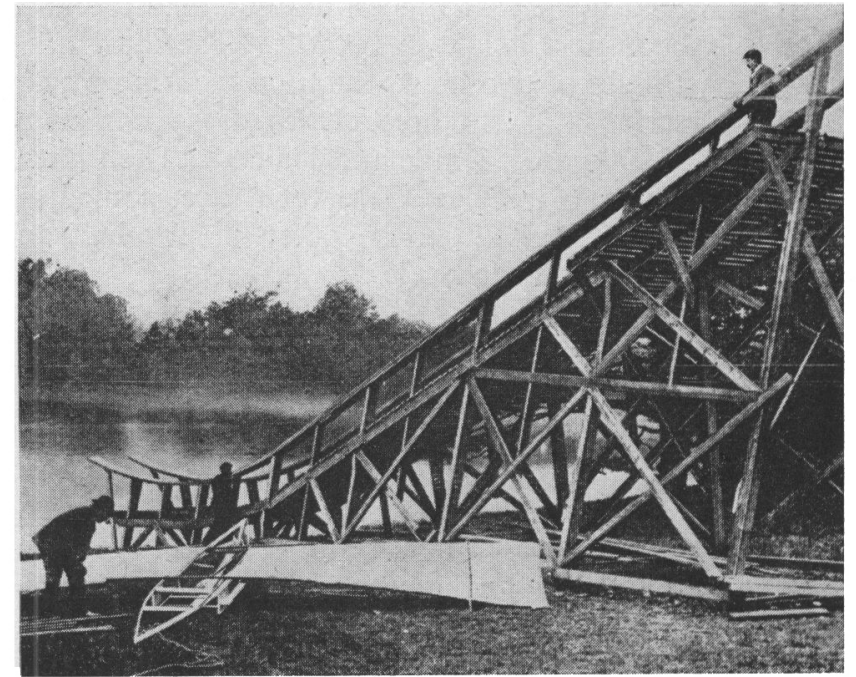

The staging for the gliding experiments at the Crystal Palace.

6. It must be capable of remaining in the open in all ordinary weather for a period of one month without very material deterioration.

7. It must be capable of flights of 2 hours duration during which it must describe various circles of varying diameters.

8. It must be capable of being kept in the air "hovering" or "circling" over any desired point, for periods of a minute or more.

9. It shall be so constructed that if the engine stops from any cause, or any portion of the machinery breaks down, there shall be a reasonable chance of the occupants reaching the ground in safety.

10. It must be so constructed that the consumption of its fuel will not upset its stability during flight.

11. It must be capable of being taken to pieces for carriage on board ship, or on rail, and of being re-assembled at any desired spot, by skilled men, within a period of 72 hours.

Some of the tests for Military Flying Machines, issued with the Specification are worth recording.

Among the flight tests and conditions it was stated:

"The trial ground shall be selected by the War Office, ordinary grass open land of an area not less than 10 acres. There may be hedges such as are usual in most parts of England on all four sides of the plot of ground, but there shall be no continuous rows of high trees, houses or telegraph wires along more than two sides of the plot."

Each candidate had to carry out five flight trials. The conditions for the first flight trial began,

"The machine shall be brought to any point of the trial ground selected by the operator, and pointed in any required direction," and "The operator shall not require any other assistance in order to start the engine or machine. The machine must rise from the ground, and fly round a captive balloon $12 \frac{1}{2}$ miles distant, and back to the starting point. The time will be taken at each point. The average pace for the 25 miles to be not less than 25 miles per hour. The pace to be calculated as follows: The rate in miles per hour going to be added to the rate in miles per hour returning, and the sum to be divided by 2 ." 
The second flight trial was an altitude one, round a captive balloon at a height of $2000 \mathrm{ft}$. The third trial called for a flight of two hours duration " during which it shall describe at least three circles of approximate diameters of 200 yards, $\frac{1}{4}$ mile and 1 mile." The fourth trial called for a War Office Observer (" accustomed to Captive Balloon work"!) to be taken up for half an hour at least $1,000 \mathrm{ft}$. and

"shall proceed in such directions as required by the Observer, and shall ' hover ' or ' circle' over a point selected by him, for at least one minute."

While this is happening the test instructions add

"It shall be possible for the Observer to look downwards from his position without his remaining in an unduly cramped attitude."

The fifth flight trial called for flights of five minutes with full tanks, and for the same period with tanks containing fuel for only ten minutes-a stability test. Petrol was calculated at the rate of half a gallon per b.h.p. of the engine.

Under the General Conditions of testing it was noted that machines were required to rise from the ground under their own power "without any special starting devices outside its own construction."

The War Office also had a clause "The Observer or Observers taking part in any flight shall volunteer to take part and shall not be ordered to do so." full.

The last clause, Clause 10, is worth being given in

"The operator shall not be required to make ascents (1) In rainy weather. (2) Where there seems to be an early probability of electric disturbances. (3) In winds of over 15 miles per hour, as measured by three flights of a pilot balloon as used in the British Service to determine the velocity of the wind. Note.-The pilots usually take the velocities at heights varying from 50 to 300 feet above the surface of the ground. (4) In the dark, or in twilight. (5) In fog or thick mist."

The years 1908 and 1909 were great years for BadenPowell. On 8th October 1908 he flew with Wilbur Wright at Le Mans in France, on the same day as C. S. Rolls, Frank Butler, and Griffith Brewer, the first Englishmen to fly. Baden-Powell's flight appears to have decided him to have no further negotiations with the War Office for there appear no further records among his papers. Achievement was far outrunning specification, and Baden-Powell must inevitably have felt that he had seen and experienced a mastery of the air not then reached by any of Wilbur Wright's contemporaries. It was, indeed, a red letter day in his long aeronautical experience.

These years saw an astonishing upsurge in all air matters. Small societies and clubs sprang into existence, most to die almost as quickly as they began. Baden-Powell sprang into the fray and found himself quickly in the middle of acrimonious and noisy discussions, public and private.

In October 1909 he presided at the Mansion House over a large meeting to discuss the formation of a representative National Council to control and encourage aviation in Great Britain. It will give some idea of the spate of air bodies which had come into existence

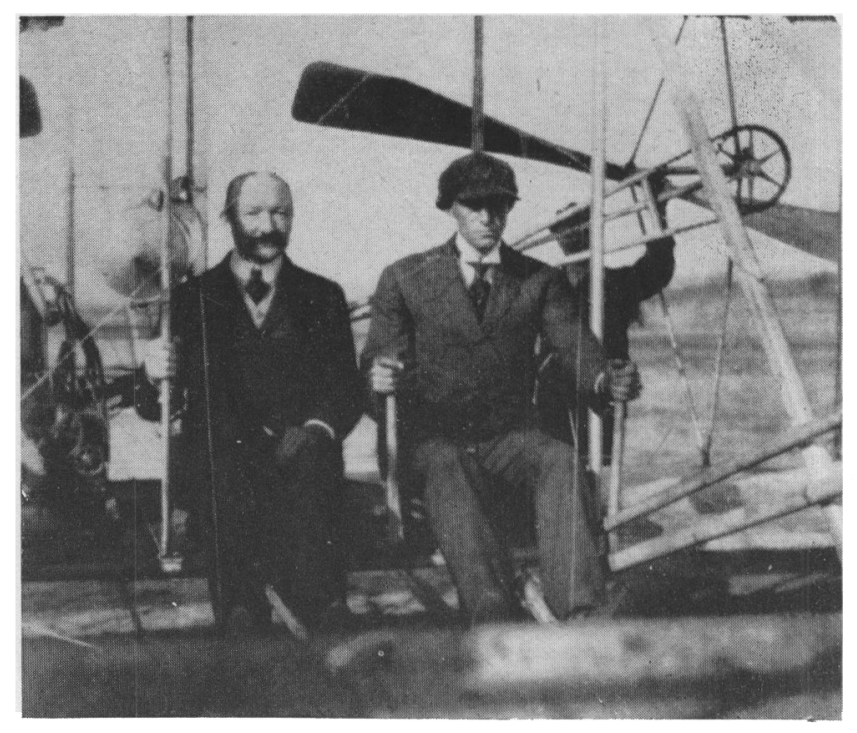

Major Baden-Powell with Wilbur Wright at Le Mans in 1908.

by the following quotation from The Times report This report does not cover all the representatives there by a long way.

"Among the societies represented were the Aeroplane Club of Great Britain, the Leicestershire Aero Club, the Northumberland Aero Club, the Midland Aero Club, the Kite Flying Association of Great Britain, the South West of England Aeronautical Society, the Scottish Aeronautical Society, the Sheffield Aero Club and other provincial clubs and societies."

The babel ultimately boiled down to nine times nothing, except for the considerable after heart-burning.

Baden-Powell had circularised the clubs and societies and air organisations in an effort to get a general agreement on what everybody should do in the coming air age. But he found that aeronautics was too aerated a drink to enable those who imbibed it to agree on much. In many respects it is perhaps fortunate for aeronautical progress that agreement is not too easy, although the difficulties may cause much heart-burning at times. I hope they always will.

Baden-Powell this year was a moving spirit in obtaining an experimental flying ground at Dagenham, where members of the Society could have their own machines for experimental flying. The ground was rough and unsuitable, and although a cinder track was prepared from which machines could take off, and sheds for housing machines, the whole scheme proved a failure. It was not, indeed, one which fitted in with the general organisation of the Society. The sheds were ultimately bought by one of today's best known aircraft designers-at a bargain price.

In March 1909 came the Aero Show at Olympia. Baden-Powell showed his $40 \mathrm{ft}$. model semi-rigid airship and a clockwork aeronautical camera which took photographs at regular intervals, and had a selfrecording apparatus to enable the altitude, direction of flight, time and so on, to be noted on each photograph at the time it was taken. 
That month The National Review published his paper, "Law in the Air." In it he put forward the necessity for a certificate of airworthiness.

"A mishap in the air, when it does occur, is liable not only to have serious consequences for the machine and its occupants, but may also do considerable damage to persons and property below. It will therefore be very necessary to establish certificates of competancy, which would probably be issued by the Board of Trade or such other body."

Baden-Powell further suggested that the rules for aerial navigation should follow those for navigation at sea, and drew attention to the serious problems created by flying over other countries' frontiers and territory, as well as over private property.

In October he gave the opening lecture of the Session at the Heriot Watt College in Edinburgh on "Recent Progress in Aerial Navigation" with the Lord Provost in the Chair.

I have noted that Baden-Powell went to see any new development or experiment in aviation whenever he could and in this lecture he related one of his experiences when visiting Count Zeppelin.

"The first time I called he gave me all the information I wanted about the balloon construction and allowed me to take the photographs $I$ am showing now. A year or two later, being in Germany again, I called upon him. He said at once, 'I am very glad to see you again,' and asked me if I played chess. When I answered that I did, he asked me to have a game. We played chess all afternoon and $\mathbf{I}$ neither heard nor saw more of the airship. The fact was that the German government had taken up the possibilities of dirigible and were in treaty with the Count."

Baden-Powell left Edinburgh to lecture, a few days later, at the Merchant Venturer's Technical College at Bristol and on 8th December, 1909 he lectured before the Royal United Services Institution on "How Airships are likely to affect war," a lecture which included aeroplanes as well as dirigibles.

The famous Field Marshal Lord Roberts was in the Chair and in his opening remarks, introducing BadenPowell, he said of flying at that time:

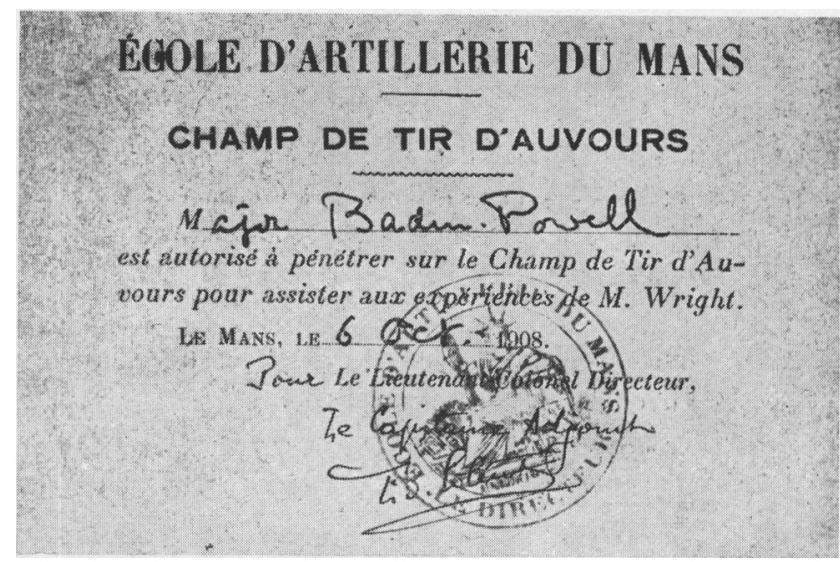

The military permission which enabled Major Baden-Powell to fly at Le Mans with Wilbur Wright.

"Something will be evoked out of all these trials, something which will perhaps astonish those who come after us as much as these present aeroplanes and dirigible balloons have astonished us, I have no doubt ... I believe that aerial machines will be a great feature in future wars and I am anxious that the country should wake up to the necessity of knowing all about them."

Lord Roberts drew attention to a book he had recently read called "The Valour of Ignorance." His words are as applicable today as they were then.

"It fits England exactly. It is the "valour of ignorance' which pervades the whole country. Our people are very brave and very confident because they know nothing about what is going on. What we have to do is to try and wake up the country; make them understand what is going on in the world."

Baden-Powell made many suggestions in his paper and they aroused a long and interesting discussion from one of the biggest audiences which had yet attended an aeronautical lecture.

One of the speakers was J. W. Dunne who had written to Baden-Powell over five years before, on 27 April, 1904, a very remarkable letter which began, " Though I am well aware of the magnitude of such a
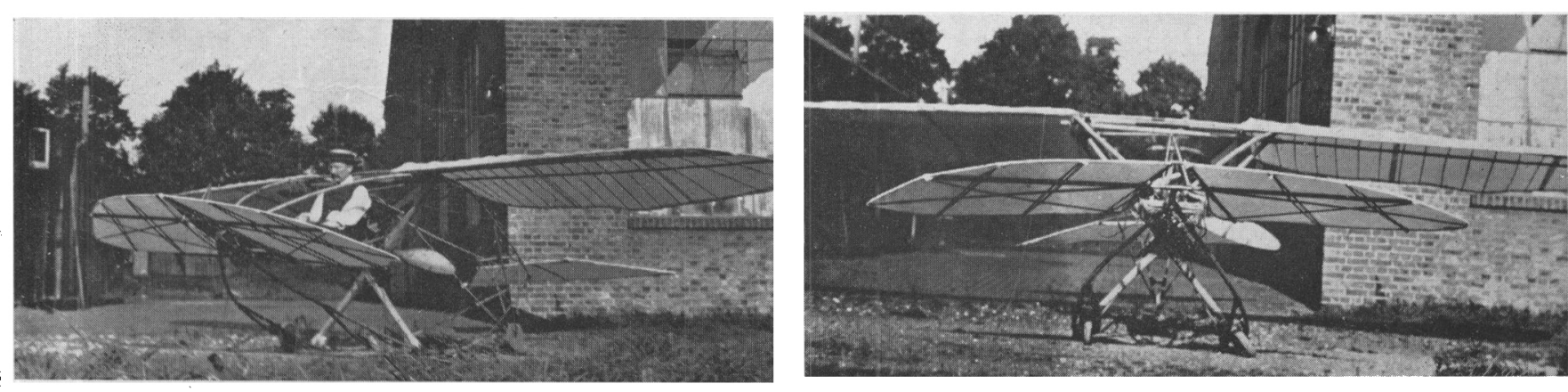

Major Baden-Powell's monoplane The Midge. Structure: American elm, streamlined where exposed. Four main members of bamboos, jointed with short steel connections. Double skids, solid wooden wheels on steel forks with spiral springs. Planes: Elevator 30 sq. ft. on universal joint. Main plane 90 sq. ft. bamboo frame. $25 \mathrm{ft}$. span, $3 \mathrm{ft} .10$ in. chord. Surface pegamoid cloth. Tail plane 20 sq. ft. on bamboo frame. Engine 12 h.p. Buchet. Wooden propeller $5 \mathrm{ft}$. $6 \mathrm{in}$. diam. Total weight, including pilot, $350 \mathrm{lb}$. Price complete, including engine and all fittings, £120. Date 1910. 
22

VOL. 60

JOURNAL OF THE ROYAL AERONAUTICAL SOCIETY

JANUARY 1956

when manet

camise dement cara crepe

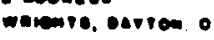

WRIGHT BROTHERS

1187 W. THing Stander

22 August 1910

Wigan 12. Bade Powell.

London.

My dean Major Baden Powell,

Th bare accept on thank for your letter contain jartieclens. Ithereideat to for f such on aces dent. If sumy bour ben canoe by.

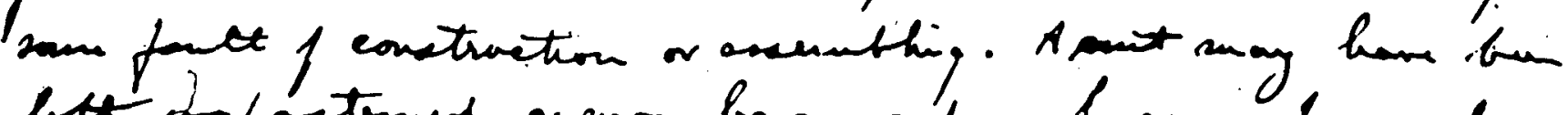

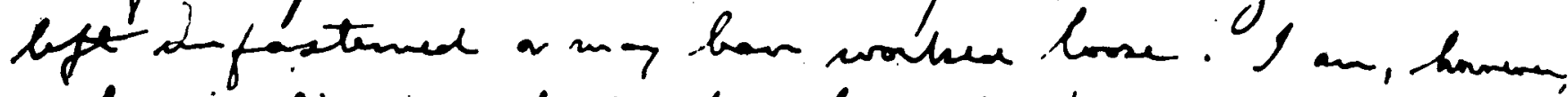

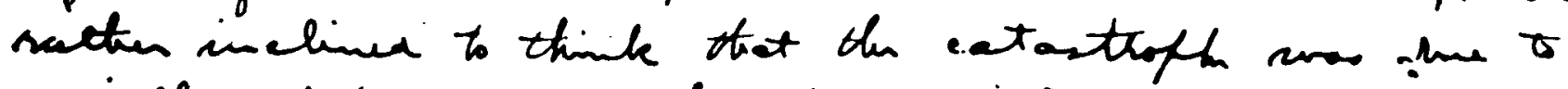

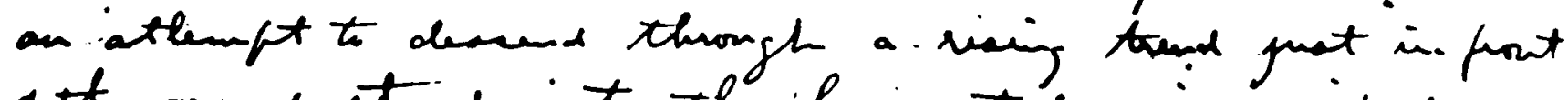
1 th grand stand int th hroiznotel wind gust beyond it. So ch et th wind caught the moahim on top and

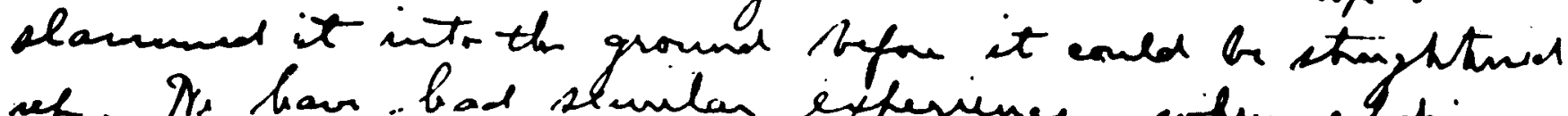

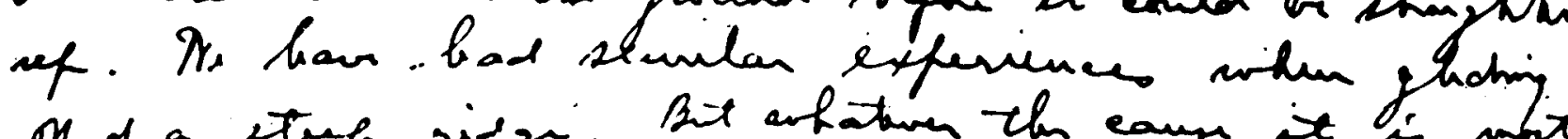

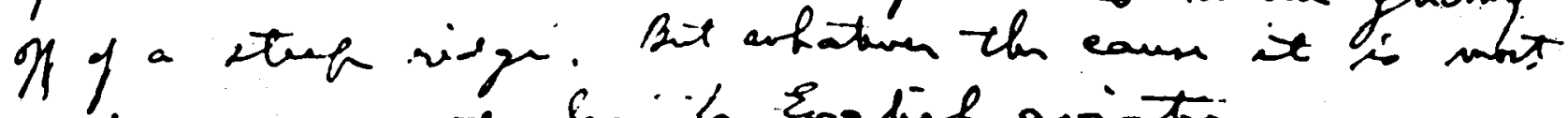

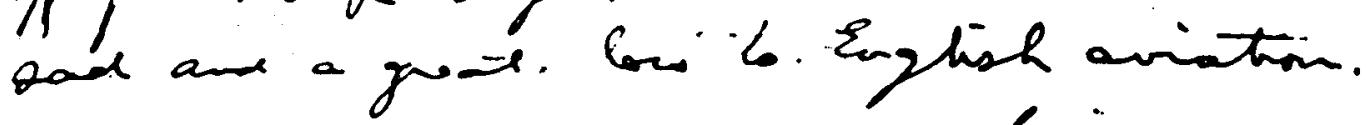

Pron orient lining gat not

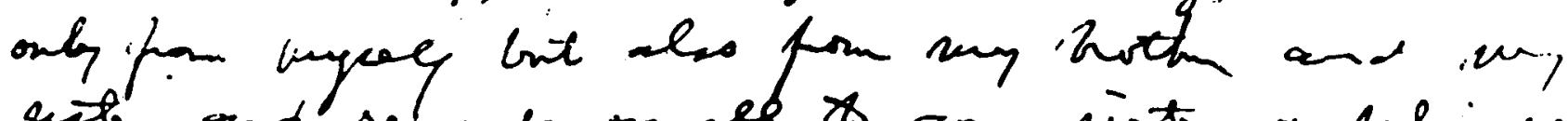

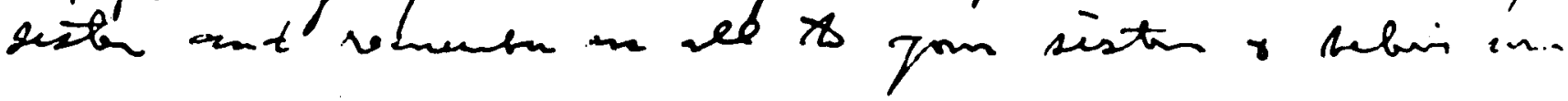
Four the Hells in Wing. $h$

Letter from Wilbur Wright to Baden -Powell on the accident which caused the death of C. S. Rolls.

https://doi.org/10.1017/S0368393100132377 Published online by Cambridge University Press 
claim, I am confident that I have threshed out and finally solved the stability in gliding aeroplanes," a claim he brilliantly justified in 1910 when he flew two miles at the Isle of Sheppey without touching the controls. The flight was officially witnessed for the Aeronautical Society by Orville Wright and Griffith Brewer. In those first few months in 1904, before the full work of the Wrights was known, Baden-Powell had discussed at length Dunne's ideas. The correspondence has been preserved and is in the possession of the Society.

One can only give a brief summary of Baden-Powell's major activties in a paper of this nature. Undoubtedly his special interest had been in his kite experiments, and he was very disappointed when the War Office failed to take a more active part when there had been such good prospects of real success. In later years he became President of the Kite Flying Association of Great Britain, of which his great rival S. F. Cody was a member of Council and W. H. Dines, a former President of the Meteorological Society, a Vice-President.

Baden-Powell's energy on behalf of the Society was astounding. He remained at the helm until the aeroplane had become a reality, He knew all the pioneers, many of whose names are now those of history. He corresponded with the famous and the not-so-famous all over the world.

When Brearey died in 1896 the Society had no address to which subscriptions or other communications from members could be sent; and in fact none of the most elementary machinery for running the Society. There was, nevertheless, much going on at the time within the knowledge and experience of Baden-Powell. Hiram Maxim, Horatio Phillips, Percy Pilcher, Octave Chanute, Lawrence Hargrave, Otto Lilienthal and others had aroused interest and anticipation. Early in 1897 (27 February) there was a lecture given at the Royal Artillery Institution, Woolwich, on aviation by a speaker whose work was to have a considerable and lasting impact on aeronautical progress, one who like Chanute, was later awarded the Gold Medal of the Society, Dr. G. H. Bryan.

The decade 1896 to 1906 was a period of pioneering endeavour and success, which gave the ten years which followed a quality which has not been obtained since. These were the years when Baden-Powell played his great part in the Society's history.

In his lecture on Aerial Navigation, which he gave before the Society of Arts on 17th April, 1907, he said,

"I am one of those who believe we are just about to enter an era of great change in human life."

He lived long enough to see the exciting beginnings of the great change, the pioneering of air transport, the courageous flights across the Atlantic and the Continents of the World, and speeds and altitudes and ranges being reached which had hardly been anticipated by the most imaginative of those who had struggled so long with "jam tomorrow and jam yesterday but never jam today," as it were.

He was a great traveller, and possessed a persistence which some found difficult at times, with a habit of wanting to be in the centre of things aeronautical. Yet he took a firm interest in quite unexpected things. I give one.

In 1910, like many others before him and after him, he believed he had hit on a system to beat the Bank at Monte Carlo, and he wrote to Sir Hiram Maxim about it.

"What you have suggested in regard to roulette is by no means new," replied Maxim, and at some length explained to Baden-Powell how the players must lose, and pointed out that the Bank had been winning a million s.nd a quarter pounds sterling annually for many years.

"However, if you wish to try a system," Maxim ended his letter, "all you have to do is to come to my house. We have a very accurate Paris-made roulette and no one can play better than her ladyship."

In April 1930, Major B. F. S. Baden-Powell completed 50 years as a member of the Society and the following telegram was sent to him from the Society he had cherished so well.

"Very cordial congratulations Mister pastPresident from the Council and members of the Society on the 50th Anniversary Monday, the 21st of your membership. Your splendid services to aeronautics and to the oldest aeronautical Society in the world will never be forgotten. Sempill. President."

I quote the words, from the letter of Sir Edwin Arnold to him on 6th August 1904. I could not better them.

"You have always most nobly and honourably believed in and struggled for the Conquest of the air for Man."

This short paper is for remembrance.

\section{Major Baden F. S. Baden-Powell}

1860 Birth

\section{A CHRONOLOGY}

1880 Witnessed his first balloon ascent. Joined the Aeronautical Society.

1881 Made his first balloon ascent. Carried out experiments on airscrews.

1882 Entered the Scots Guards

1883 Lectured on "Military Ballooning " to the Royal United Services Institution. Visited Paris to see the Tissandier dirigible.

1884 Visited French aeronautical station at Meudon and saw the French Army dirigible La France. Late in year sailed to Africa to take part in the Nile Campaign.

1885 In Africa, during Nile Campaign.

1886 Attended German and Russian manoeuvres and reported to British War Office.

Elected a member of Council of Aeronautical Society.

1887 Paper "How I learnt ballooning" in Temple Bar for March. Began his studies on man-lifting kites.

1888/91 In Queensland, Australia, as A.D.C. to the Governor. Took part in New Guinea with a punitive force and travelled in Java and Borneo. Published his book In Savage Isles and Settled Lands. 


24 VOL. 60 JOURNAL OF THE ROYAL AERONAUTICAL SOCIETY

1893 Began kite experiments. First published record of taking part in Society's lecture discussions.

1894 April. First man to be raised by a kite into the air. Travelled to West Coast of Africa.

1895 Lecture on "Kites: their uses in War" to the Royal United Services Institution.

Second visit to West Coast of Africa. Sent in full report of French fortifications to British War Office.

Paper in November Blackwood's Magazine, "A trip Heavenward."

Paper in December National Review, "The aircar."

1896 Becomes Honorary Secretary of the Society. Attached to Balloon School at Aldershot for kite experiments.

1897 FOUNDS AERONAUTICAL JOURNAL.

Paper in Royal United Services Magazine for April, "The Conquest of the Air."

1898 Lecture on "Kites. Their theory and practice" in March to the Society of Arts.

Awarded the Silver Medal of Society of Arts.

Paper in Pearson's Magazine "War Kites."

Paper on "Balloons for Geographical Research" before the British Association.

1899 South Africa-Boer War.

1900 October. Elected President of the Society while in S. Africa.

Paper on "The Secretary Bird" in July Aeronautical Journal.

1901 In South Africa.

1902 Paper in January Aeronautical Journal on "War Balloon in S. Africa."

Presidential Address to the Society, December, on "Recent Aeronautical Progress."

1903 Published book War in Practice.

Paper in September The Car Magazine, "Aeroplanes and Flying Machines."

Paper in September Illustrated Scientific News, "Progress with Airships."

Constructed large model airship with $1 \frac{1}{2}$ h.p. engine.
1904 Paper in June and July Knowledge, "Aeroplane Experiments."

Paper in April Aeronautical Journal, "Experiments with screw propellers."

Paper in July Aeronautical Journal on his gliding experiments at the Crystal Palace.

Paper to British Association at Cambridge on

"The Development of the Aeroplane."

Visits St. Louis Exposition at which he gave the opening paper.

Retires from the Army.

1905 Paper in May Fortnightly Review, " Airships and and Santos-Dumont."

1906 Paper in May National Review, “The advent of the flying machine."

Paper in the October The Car, "In an Italian War balloon."

1907 Paper in Journal of the Royal Meteorological Society for July, "The Exploration of the Air." Published his book "Ballooning as a Sport."

Founded Aeronautics.

Lecture to the Society of Arts in April, "Aerial Navigation."

Resigns the Presidency of the Society.

1908 Paper in November Nineteenth Century, "The Problem of Aerial Navigation."

Paper in Aeronautical Journal, "Experiments with dipping planes."

Elected Vice-President of the Society.

8th October. Flies with Wilbur Wright.

1909 Paper in March National Review, "Law in the Air."

Paper in October Aeronautical Journal, "Some lesssons from Rheims."

Paper in January Aeronautical Journal, " Experiences with the Wright machine."

1910 Designs The Midge light aeroplane.

Edits book of formulae, Alexander's Aeronautics.

1911 Lecture in April to Junior Institution of Engineers, "Recent Progress in Aeronautics."

1914/18 Rejoined Scots Guards and fought in France.

1919 Elected an Honorary Fellow.

1930 Fiftieth anniversary of joining the Society.

1937 Death. 